\title{
PENERAPAN MODEL PEMBELAJARAN KOOPERATIF TIPE NUMBERED HEADS TOGETHER (NHT) UNTUK MENINGKATKAN AKTIFITAS DAN HASIL BELAJAR MENYUSUN RENCANA ANGGARAN BIAYA (MRAB) SISWA KELAS XI TEKNIK KONSTRUKSI BATU DAN BETON SMK NEGERI 1 BALIGE
}

\author{
Sam Welson Sitinjak ${ }^{1}$, Jintar Tampubolon ${ }^{2}$ \\ ${ }^{1}$ Alumni Program Studi Teknik Bangunan, Fakultas Teknik UNIMED \\ ${ }^{1}$ Dosen Pengajar Jurusan Pendidikan Teknik Bangunan, Fakultas Teknik UNIMED \\ (Jintar_tampubolon@yahoo.com)
}

\begin{abstract}
ABSTRAK
Penelitian ini bertujuan untuk mengetahui peningkatan aktifitas dan hasil belajar menyusun rencana anggaran biaya siswa kelas XI program keahlian Teknik Konstuksi Batu dan Beton SMK Negeri 1 Balige melalui model pembelajaran Numbered Heads Together. Penelitian ini merupakan penelitian tindakan kelas yang dilakukan pada semester ganjil tahun pelajaran 2014/2015 dengan jumlah siswa 32 orang. Dari hasil uji coba instrumen yang terdiri dari 20 soal pada siklus I, hanya 15 soal yang dapat digunakan dengan keterangan 15 soal yang valid, indeks kesukaran soal diperoleh 5 butir soal dalam kategori baik, 9 kategori sedang dan 6 kategori mudah, daya beda soal diperoleh 9 soal cukup, 11 soal jelek dan uji reliabilitas 0,81 (sangat tinggi). Sedangkan untuk 20 soal di siklus II, hanya 15 soal yang dapat digunakan dengan keterangan 15 soal valid, indeks kesukaran diperoleh 7 butir soal dalam kategori baik, 10 kategori sedang dan 3 kategori mudah, daya beda soal diperoleh 4 soal baik, 11 soal cukup, 5 soal jelek, uji reliabilitas 0,77 (tinggi)

Penelitian ini dilakukan dalam dua siklus yang masing masing terdiri dari dua kali pertemuan. Setiap siklus terdiri dari tahap perencanaan (planning), pelaksanaan (acting), pengamatan (observating), dan refleksi (reflecting). Teknik pengumpulan data dengan observasi dan tes hasil belajar.

Berdasarkan hasil evaluasi proses pada setiap pembelajaran dan berdasarkan observasi keaktifan atau aktifitas siswa dalam penelitian ini, ditemukan siklus I nilai rata-rata aktifitas belajar siswa yaitu 65,82 meningkat sebesar $6,33 \%$ menjadi 72,25 pada siklus II. Untuk nilai hasil belajar pada siklus I yaitu 70,64 dan meningkat sebesar 11,36\% menjadi 82 pada siklus II. Hasil penelitian menunjukkan bahwa penerapan model pembelajaran Kontekstual dapat meningkatkan aktifitas belajar siswa, serta meningkatkan hasil belajar siswa pada mata pelajaran Menyusun Rencana Anggaran Biaya.
\end{abstract}

Kata Kunci : Model Pembelajaran Kooperatif, NHT, Hasil Belajar, MRAB

\begin{abstract}
This study aims to improve the students activity and learning outcomes prepare a budget plan Subject class XI Architecture Engineering skills program SMK Negeri 1 Balige through numbered heads together learning model. This research is a classroom action research that is performed on first semester of academic year 2014/2015 the number of students 32 people.

From the test results performed on the instrument cycle I gained 15 of the 20 valid questions that matter, about the difficulty index is obtained by category about good 5, being 9 and 6 about the easy category. Different power gained about, 9 about enough, about 11 ugly, test reliability 0,81 (very high) and the second cycle was obtained 15 valid matter of 20 questions, the index gained 7 good, 10 questions about the difficulty of being , 3 easy


questions. Different power gained about 4 good questions, 11 questions enough, 5 about the ugly, test reliability of 0.77 ( high).

This research was conducted in two cycles in the first cycle consists of two meetings and the second cycle consists of two meetings. Each cycle consisted of a planning phase (planning), action (acting), observations ( observating ), and reflection ( reflecting). The technique of collecting data through observation and achievement test. Based on the evaluation and learning process at each observation based on the activity or activities of students in this study, it was found the first cycle of the average value of student learning activities which increased by $6.33 \%, 65.82$ into 72.25 in the second cycle. To the value of learning outcomes in the first cycle is 70.64 and increased by $11.36 \%$ to 82 in the second cycle. The results showed that the application of Numbered Heads Together Learning model can 1 ) improve students' learning activities , 2 ) improving student learning outcomes in prepare a budget plan subject.

Keywords : Cooperative Learning Model, NHT, Learning Outcomes, RAB

\section{Pendahuluan}

Upaya menghasilkan sumber daya manusia (SDM) yang berkualitas diperlukan penguasaan ilmu pengetahuan dan teknologi yang memadai yang diwujudkan melalui kegiatan pembelajaran dan pendidikan yang merupakan proses pembentukan kemampuan dasar yang fundamental, baik yang menyangkut daya pikir maupun daya emosional yang diarahkan kepada tabiat manusia dan kepada sesamanya.

Menurut Kurikulum Tingkat Satuan Pendidikan (KTSP) Sekolah Menengah Kejuruan tahun 2006, bahwa SMK memiliki tujuan khusus, yaitu : 1). Menyiapkan peserta didik agar menjadi manusia produktif, mampu bekerja mandiri, mengisi lowongan pekerjaan yang ada di dunia usaha dan dunia industri sebagai tenaga kerja tingkat menengah sesuai dengan kompetensi dalam program keahlian yang dipilih, 2). Menyiapkan peserta didik agar mampu memilih karir, ulet dan gigih dalam kompetensi, beradaptasi dilingkungan kerja dan mengembangkan sikap profesional dalam bidang keahlian yang diminatinya, 3). Membekali peserta didik dengan ilmu pengetahuan, teknologi dan seni, agar mampu mengembangkan diri di kemudian hari baik secara mandiri maupun melalui jenjang pendidikan yang lebih tinggi, 4). Membekali peserta didik dengan kompetensi-kompetensi yang sesuai dengan program keahlian yang dipilih

Dari uraian di atas, SMK sebagai salah satu lembaga pendidikan dalam bidang kejuruan diharapkan dapat menghasilkan lulusan SMK yang memiliki pengetahuan dan keterampilan yang siap pakai di lapangan kerja dan bahkan diharapkan mampu menciptakan lapangan kerja yang sesuai dengan keahlian yang dimilikinya.

Namun kenyataannya bahwa lulusan SMK masih kurang mampu bersaing dalam dunia kerja, selain itu mereka juga kurang mampu menciptakan peluang-peluang sendiri berdasarkan keterampilan yang didapat dibangku sekolah (Slameto,2003).

Dari hasil observasi yang dilakukan di SMK N 1 Balige pada tanggal 14 juni 2014, diperoleh data nilai ujian formatif sebagai berikut:

Tabel 1. Persentase Hasil Belajar MRAB Kelas XI Teknik Konstruksi Batu dan Beton SMK Negeri 1 Balige Tahun Ajaran 2013/2014

\begin{tabular}{ccccc}
\hline No & Nilai & Fo $_{\mathbf{o}}$ & $\begin{array}{c}\mathbf{F r} \\
(\%)\end{array}$ & KETERANGAN \\
\hline $\mathbf{1}$ & $90-100$ & 0 & 0 & $\begin{array}{c}\text { Sangat } \\
\text { Kompeten }\end{array}$ \\
$\mathbf{2}$ & $80-89$ & 1 & 5,3 & $\begin{array}{c}\text { Kompeten } \\
\text { Cukup } \\
\text { Kompeten } \\
\text { Kurang } \\
\text { Kompeten }\end{array}$ \\
\hline
\end{tabular}

\begin{tabular}{llll}
\hline \multicolumn{1}{c}{ Jumlah } & 19 & 100 & \\
\hline (Sumber:Kumpulan Nilai Ujian formatif & Siswa \\
Menyusun Rencana & Anggaran Biaya & (MRAB) & SMK \\
Negeri 1 Balige) & & &
\end{tabular}

Dengan memperhatikan tabel di atas bahwa pada tahun ajaran 2013/2014 semester genap dengan jumlah peserta didik 19 orang, yang memperoleh nilai $<70$ sebanyak $31,5 \%$ (6 orang), nilai $70-79$ sebanyak $63,2 \%$ (12 orang) 
dan nilai $80-89$ sebanyak 5,3\% (1 orang). Dan berdasarkan keterangan guru yang bersangkutan nilai ini pun telah mengalami penyiraman yang didasarkan pertimbanganpertimbangan, seperti: kehadiran, keaktifan dalam proses belajar mengajar, sikap dan tingkah laku dengan KKM mata pelajaran MRAB adalah nilai 70 .

Dari fakta di atas dapat disimpulkan bahwa aktifitas dan hasil belajar siswa pada mata pelajaran MRAB, tergolong dalam kategori rendah, Untuk mengatasi hasil belajar siswa yang belum memenuhi standar kelulusan, maka diperlukan upaya-upaya dari guru untuk meningkatkan hasil belajar siswa tersebut. Salah satu upaya yang dapat dilakukan adalah dengan menggunakan model Pembelajaaran Kooperatif (cooperative learning). Dalam cooperative learning terdapat variasi model yang dapat diterapkan, salah satu diantaranya adalah model pembelajaran NHT (Numbered Heads Together).

Dalam model pembelajaran kooperatif tipe NHT, siswa menempati posisi sangat dominan dalam proses pembelajaran dan terjadinya kerja sama dalam kelompok dengan ciri utamanya adanya penomoran dalam kelompok sehingga semua siswa berusaha untuk memahami setiap materi yang diajarkan dan bertanggung jawab atas nomornya masingmasing. Dengan pemilihan model ini, diharapkan pembelajaran yang terjadi dapat lebih bermakna dan memberi kesan yang kuat kepada siswa. Pembelajaran kooperatif tipe NHT juga dinilai lebih memudahkan siswa berinteraksi dengan teman-teman dalam kelas dibandingkan dengan model pembelajaran langsung yang selama ini diterapkan oleh guru.

Dengan dasar inilah yang mendorong peneliti mencoba mengadakan penelitian dalam bentuk penelitian tindakan kelas dengan judul Penerapan Model Pembelajaran Kooperatif Tipe Numbered Heads Together (NHT) Untuk Meningkatkan Aktifitas dan Hasil Belajar Menyusun Rencana Angagaran Biaya (MRAB) Siswa Kelas XI Teknik Konstruksi Batu dan Beton SMK Negeri 1 Balige.

\section{Kajian Pustaka}

\subsection{Hakekat Aktifitas Belajar}

Menurut Sardiman (2004: 99) mengatakan bahwa aktifitas belajar merupakan serangkaian kegiatan yang meliputi keaktifan siswa dalam mengikuti pelajaran, bertanya, mencatat, mendengar, berpikir, membaca dan segala kegiatan yang dilakukan yang dapat menunjang prestasi belajar.

Dalam aktifitas belajar ada beberapa prinsip yang berorientasi pada pandangan ilmu jiwa, yakni menurut pandangan ilmu jiwa lama dan ilmu jiwa modern. Menurut pandangan ilmu jiwa lama aktifitas didominasi oleh guru sedang menurut ilmu jiwa modern aktifitas didominasi oleh siswa.

Adapun jenis-jenis aktifitas dalam belajar yang digolongkan oleh Paul B. Diedric (Sardiman, 2011: 101) adalah sebagai berikut:

a. Visual Activities, contohnya membaca, memperhatikan gambar demonstrasi, percobaan, mengamati pekerjaan orang lain dan sebagainya.

b. Oral Activities, contohnya menyatakan, merumuskan, bertanya, memberi saran, berpendapat, diskusi, interupsi dan sebagainya.

c. Listening Activities, contohnya mendengarkan uraian, percakapan, diskusi, musik, pidato dan sebagainya.

d. Writing Activities, contohnya menulis cerita, karangan, laporan, menyalin dan sebagainya.

e. Drawing Activities, contohnya menggambar, membuat grafik, peta, diagram dan sebagainya.

f. Motor Activities, contohnya melakukan percobaan, membuat konstruksi, model, mereprasi, berkebun, beternak dan sebagainya.

g. Mental Activities, contohnya menanggapi, mengingat, memecahkan soal, menganalisis, mengambil kesimpulan dan sebagainya.

h. Emotinal Activities, contohnya merasa gugup, berani, bosan, melamun, tenang dan sebagainya.

Dari uraian diatas, dapat diambil pengertian aktifitas belajar adalah kegiatan yang meliputi keaktifan siswa dalam kegiatan proses belajar mengajar baik berupa sikap, pikiran, mental, dan perhatian yang bertujuan untuk mendukung keberhasilan dan memperoleh dari manfaat dari kegiatan belajar tersebut.

Menurut Hamalik (2009) "hasil belajar adalah terjadinya perubahan tingkah laku pada diri siswa, yang dapat diamati dalam bentuk perubahan pengetahuan, sikap, dan 
ketrampilan". Menurut Bloom (dalam Sardiman, 2009), ada tiga kemampuan yang diharapkan siswa sebagai hasil belajar yaitu :

a. Kognitif Domain, yaitu perilaku yang berhubungan dengan pengetahuan, ingatan, pemahaman, menjelaskan, menguraikan, merencanakan, menilai, dan menerapkan.

b. Affective Domain, yaitu perilaku yang berhubungan dengan sikap menerima, memberikan respons, menilai, organisasi dan karakteristik.

c. Psycomotor Domain, yaitu perilaku yang berhubungan dengan ketrampilan atau skill yang berkaitan dengan fisik.

Dari pendapat di atas, maka dapat diambil kesimpulan bahwa hasil belajar adalah kemampuan yang dimiliki siswa setelah mengalami proses belajar dan adanya perubahan tingkah laku (pengetahuan, sikap, dan keterampilan) kearah yang lebih baik yang terjadi pada individu atau kelompok.

\section{Metodologi Penelitian}

Penelitian ini dilaksanakan di SMK Negeri 1 Balige kelas XI Program Keahlian Konstruksi Batu dan Beton tahun ajaran 2014/2015, Waktu penelitian dilaksanakan pada semester ganjil pada bulan November 2014 sampai dengan selesai.

Adapun langkah-langkah yang akan dilakukan dalam proses penelitian ini adalah :

a. Melakukan observasi lingkungan sekolah, guru yang sedang mengajar dan siswa yang menjadi objek penelitian.

b. Melakukan diskusi dengan PKS I dan bekerjasama dengan guru mata pelajaran MRAB untuk menganalisis kurikulum tentang penerapan model pembelajaran NHT dalam belajar. Melakukan proses pembelajaran dengan menggunakan model pembelajaran NHT, dengan menjelaskan terlebih dahulu cara kerja model pembelajaran NHT kepada siswa. Melakukan proses pembelajaran dengan menggunakan model pembelajaran NHT, dengan menjelaskan terlebih dahulu cara kerja model pembelajaran NHT kepada siswa.

c. Setelah proses pembelajaran dengan menggunakan model pembelajaran NHT selesai maka siswa diberikan tes dengan tujuan untuk mengetahui apakah hasil belajar siswa mengalami
peningkatanMelakukan proses pembelajaran dengan menggunakan model pembelajaran NHT, dengan menjelaskan terlebih dahulu cara kerja model pembelajaran NHT kepada siswa.

d. Setelah proses pembelajaran dengan menggunakan model pembelajaran NHT selesai maka siswa diberikan tes dengan tujuan untuk mengetahui apakah hasil belajar siswa mengalami peningkatanMelakukan proses pembelajaran dengan menggunakan model pembelajaran NHT, dengan menjelaskan terlebih dahulu cara kerja model pembelajaran NHT kepada siswa.

e. Setelah proses pembelajaran dengan menggunakan model pembelajaran NHT selesai maka siswa diberikan tes dengan tujuan untuk mengetahui apakah hasil belajar siswa mengalami peningkatan

Setelah proses pembelajaran dengan menggunakan model pembelajaran NHT selesai maka siswa diberikan tes dengan tujuan untuk mengetahui apakah hasil belajar siswa mengalami peningkatan.

\subsection{Siklus I}

\subsubsection{Perencanaan}

Maka perencanaan yang akan dilakukan di siklus I adalah sebagai berikut:

a. Melakukan analisis kurikulum untuk mengetahui kompetensi dasar yang akan disampaikan kepada siswa dengan menggunakan model pembelajaran Kontekstual

b. Membuat rencana pembelajaran Kontekstual

c. Membuat lembar kerja siswa

d. Membuat instrumen yang digunakan dalam siklus PTK

e. Menyususn alat evaluasi pembelajaran

\subsubsection{Pelaksanaan Tindakan}

Dalam setiap siklus dilaksanakan dengan durasi waktu $4 \times 45$ menit. Pada siklus pertama, pertemuan ini diawali dengan sub materi deskripsi ukur tanah. Pembelajaran dilakukan dalam tiga tahap, yaitu tahap pendahuluan, tahap inti dan tahap penutup. Pada tahap pendahuluan guru bidang studi menjelaskan model dan tujuan pembelajaran. Tahap inti, yaitu pelaksanaan model pembelajaran Kontekstual diawali dengan 
memperkenalkan model pembelajaran Kontekstual kepada siswa. Kemudian peneliti membagi naskah pembelajaran kepada siswa pada sub materi deskripsi ukur tanah. Dalam hal ini, guru mengembangkan komponen pembelajaran kontekstual selama proses belajar mengajar berlangsung melalui langkahlangkah pembelajaran kontekstual. Langkah petama yaitu mengembangkan pemikiran siswa untuk melakukan kegiatan belajar lebih bermakna dengan cara bekerja sendiri, dan mengkonstruksi sendiri pengetahuan dan keterampilan baru yang akan dimiliki oleh siswa. Kemudian melaksanakan kegiatan inquiri sejauh mungkin. Selanjutnya guru akan membangkitkan rasa ingin tahu siswa dengan memunculkan pertanyaanpertanyaan terkait dengan materi pembelajaran. Langkah selanjutnya adalah menciptakan masyarakat belajar dengan cara memmbuat tanya jawab. Setelah itu, guru memberikan ilustrasi yang bertujuan menggambarkan pengukuran suatu wilayah. Selama proses tersebut di atas, peneliti dan kolaborator (guru) melakukan pengamatan terhadap aktivitas siswa sekaligus melakukan penilaian. Pada kegiatan penutup peneliti dan kolaborator melakukan refleksi dari setiap kegiatan pembelajaran yang telah dilakukan, kemudian melakukan penilaian secara objektif, memberikan tugas rumah kepada siswa dan memberikan gambaran materi yang akan dipelajari pada pertemuan selanjutnya

Pertemuan kedua diawali dengan memberikan beberapa pertanyaan tentang materi yang sudah dipalajari sebelumnya yang bertujuan untuk mengingat apa yang telah dipelajari siswa sekaligus untuk mengembangkan pemikiran siswa. Kemudian guru melanjutkan materi peajaran memasuki materi selanjutnya, yaitu ruang lingkup ilmu ukur tanah. Kemudian dilanjuktkan dengan langkahlangkah pembelajaran kontekstual seperti pada pertemuan pertama. Pada pertemuan ini, siswa terlihat lebih memahami model pembelajaran kontekstual dibandingkan dengan pertemuan pertama. Hal ini diikuti dengan sedikit perkembangan dalam hal berfikir, bekerja sendiri, memberikan tanggapan dan dalam hal bertanya.

\subsubsection{Pengamatan}

Dalam penelitian tindakan kelas, observasi dilaksanakan dengan beberapa aspek yang diamati adalah sebagai berikut:

a. Mengamati aktivitas belajar siswa dalam proses pembelajran berlangsung

b. Menganalisa hasil tes dan observasi pada pelaksanaan tindakan untuk menetapkan tingkat keberhasilan

\subsubsection{Refleksi}

Refleksi dilakukan dengan menganalisis hasil kerja peserta didik, lembar pengamatan yang telah diisi dari hasil diskusi yang dilakukan peneliti dan pengamat.

Adapun Refleksi:

a. Mengkaji berbagai hal yang terjadi dan seharusnya dilakukan

b. Membuat kesimpulan sebagai dasar untuk melaksanakan siklusberikutnya

\subsection{Siklus II}

Pada prinsipnya semua kegiatan siklus II mirip dengan siklus I. Siklus II merupakan perbaikan pada siklus I, terutama didasarkan atas hasil refleksi pada siklus I. Secara garis besarnya adalah sebagai berikut.

\subsubsection{Perencanaan}

Meninjau kembali rancangan pembelajaran yang disiapkan untuk siklus 2 dengan melakukan revisi sesuai hasil refleksi 1. Adapun perencanaan nya

a. Mengidentifikasi masalah yang muncul pada siklus I dan penetapan alternatif pemecahan masalah

b. Merencanakan pengembangan program yang dilakasanakan pada siklus II, untuk menyelesaikan permasalahan pada siklus I.

\subsubsection{Pelaksanaan Tindakan}

Pelaksanaan tindakan yang akan dilakukan adalah sama seperti pelaksanaan pada siklus I. 


\subsubsection{Pengamatan}

Guru dan peneliti melakukan pengamatan yang sama seperti pada siklus I.

\subsubsection{Refleksi}

Refleksi pada siklus II ini dilakukan untuk melakukan penyempurnaan pembelajaran dengan menggunakan pembelajaran Kontekstual di harapkan dapat meningkatkan Aktivitas dan hasil belajar peserta didik.

\subsection{Teknik Pengumpulan Data}

Teknik pengumpulan data dalam penelitian ini menggunakan tes dan Observasi Aktvitas . Teknik tes digunakan memperoleh data hasil belajar Ukur Tanah siswa dan Observasi digunakan untuk mengetahui Aktivitas belajar siswa.

\subsubsection{Observasi Aktivitas Siswa}

Obsevasi digunakan untuk mengumpulkan data tentang aktivitas belajar siswa dalam proses belajar mengajar dan penerapan model pembelajaran Kontekstual. Observasi yang dilakukan dalam penelitian ini dengan mengunakan lembar Observasi aktivitas siswa dalam kelompok dengan menganalisis tingkat keaktifan siswa dalam proses belajar mengajar berlangsung.

a. Aspek Aktivitas yang dinilai

1. Visual activities (Memperhatikan soal yang akan di bahas dalam diskusi)

2. Oral activities (Bertanya dan mengemukakan pendapat dan saran)

3. Drawing activities (membuat tabel)

4. Mental activities (memberi tanggapan, memecah soal,menaati peraturan).

b. Kriteria skor

1 = Tidak pernah melakukan

$2=$ Dilakukan namun jarang $(1 \mathrm{x}-2 \mathrm{x})$

3 = Sering dilakukan

4 = Sangat sering dilakukan

c. Kriteria Penilaian

Menurut Sudjiono yang di posting oleh Y Jamiah, kriteria persentase aktivitas sebagai berikut:

$$
\begin{aligned}
& \% \text { keaktifan }=\frac{\text { Skor } \text { yang diperoleh }}{\text { skor } \text { maksimum }} \boldsymbol{x} \mathbf{1 0 0} \\
& \text { Kriteria Penilaian: } \\
& 75 \%<\text { keaktifan } \leq 100 \% \text { tergolong sangat } \\
& \text { aktif } \\
& 65 \%<\text { keaktifan } \leq 74 \% \text { tergolong aktif } \\
& 55 \%<\text { keaktifan } \leq 64 \% \text { tergolong cukup aktif } \\
& 0 \%<\text { keaktifan } \leq 54 \% \text { tergolong kurang aktif }
\end{aligned}
$$

\subsubsection{Tes Hasil Belajar}

Tes yang digunakan dalam penelitian disesuaikan dengan tujuan yang hendak dicapai. Adapun tes yang diberikan berbentuk Pilihan berganda sebanyak 29 soal dengan empat pilihan, dan dibagi dua, dimana 15 soal untuk siklus pertama dan 14 untuk siklus kedua.

4. Hasil Penelitian dan Pembahasan

4.1 Hasil Observasi Aktifitas Siswa dalam Proses Belajar Mengajar Siklus I

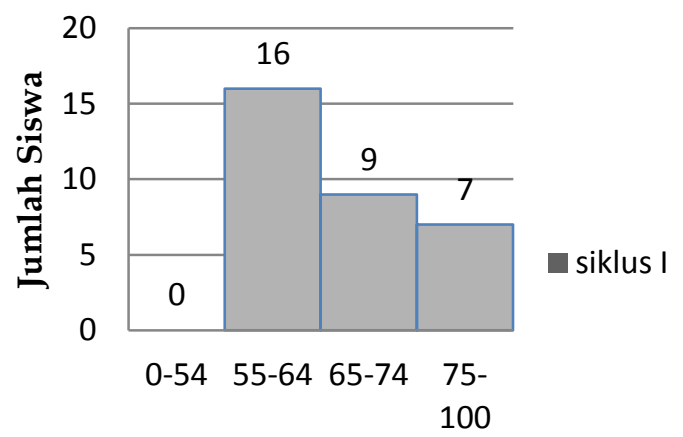

Rentang Nilai

Gambar 1. Diagram Aktivitas Belajar Siswa Siklus I

Dari data hasil observasi terhadap aktifitas belajar siswa terdapat empat aspek yang dinilai kepada 32 siswa, dimana siswa yang memperoleh kategori Kurang Aktif tidak ada, Cukup Aktif 16 orang, Aktif 9 orang dan kategori Sangat Aktif 7 orang. Sesuai dengan data tersebut maka aktifitas siswa dapat dikatakan sudah berhasil, tetapi mayoritas siswa masuk dalam kategori Cukup Aktif dan belum diketahui apakah aktifitas siswa akan meningkat atau tidak, sehingga penelitaian dilanjutkan ke siklus II dengan menerapkan model pembelajaran NHT dan memperhatikan 
kelemahan yang terjadi selama pelaksanaan siklus I.

\subsection{Hasil Belajar Siswa Siklus I}

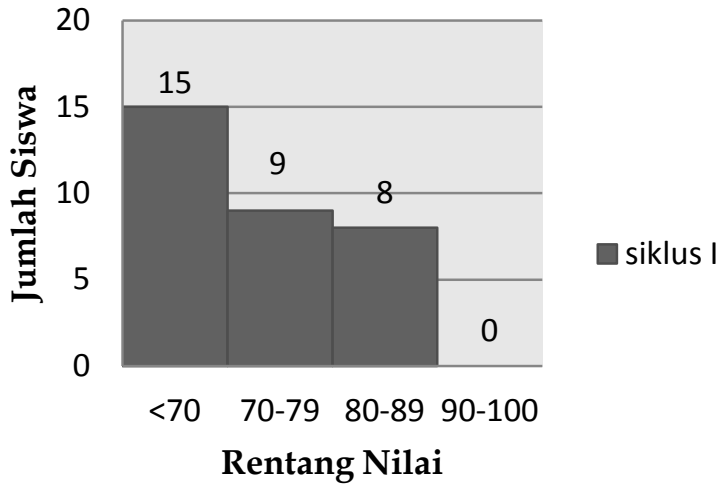

Gambar 2. Diagram Hasil Belajar Siswa Siklus I

Dari hasil belajar yang diperoleh siswa waktu pelaksanaan tindakan selesai maka diketahui hasil belajar siswa dengan kategori tidak kompeten 15 siswa $(46,875 \%)$, kategori kompeten 9 siswa $(28,125 \%)$, kategori cukup kompeten 8 siswa $(25 \%)$, dan untuk kategori sangat kompeten tidak ada.

Berdasarkan data hasil pengamatan pada siklus I menunjukkan bahwa aktifitas dan hasil belajar siswa belum memenuhi target yang diharapkan. Hal ini dapat diketahui dari:

a. Dalam penerapan model pembelajaran NHT ini, penggunaan waktu yang tertulis dalam RPP masih belum sesuai dengan perincian langkah-langkah yang telah direncanakan alokasi waktunya.

b. Hampir semua siswa bingung dengan model pembelajaran NHT ini, mengapa masih ada nomor dalam kelompok.

c. Sebagian besar siswa Kurang Aktif dalam diskusi kelompok, menjawab pertanyaan guru, memberikan tanggapan dan dalam menyimpulkan pelajaran di akhir proses belajar mengajar.

Untuk memperbaiki kelemahan dan mempertahankan keberhasilan yang telah tercapai pada siklus pertama, maka dilanjutkan ke siklus kedua dengan rencana sebagai berkut: a. Memusatkan perhatian siswa pada pelajaran yang sedang berlangsung, sehingga pemikiran siswa dapat berkembang, dapat menemukan sendiri apa yang belum mereka ketahui dengan bantuan guru, sehingga dapat mencapai target dari model pembelajaran NHT ini.

b. Menjelaskan kepada \$iswa tujuan penomoran dalam kelompok supaya mereka bertanggung jawab atas nomornya, karena guru bisa saja memanggil semua siswa yg nomornya sama untuk membandingkan jawaban/tanggapan atas pertanyaan guru

c. Membuat pertanyaan yang lebih banyak kepada siswa untuk memhacu keaktivan siswa, memberikan nilai tanhbah bagi siswa yang bekerja sama dengan baik dalam kelompok, maupun kepada siswa atau kelompok yang dapat menjawab pertanyaan dengan benar, hal ini bertujuan untuk memperkuat kerjasama dalam kelompok. Dengan demikian diharapkan dapat meningkatkan aktifitas dan hasil belajar siswa.

d. Memberikan bantuan kepada siswa yang masih bingung dengan model pembelajaran ini, dengan cara memberikan pengertian dan penjelasan secara khusus bagi siswa tersebut.

4.3 Hasil Observasi Aktifitas Siswa dalam Proses Belajar Mengajar Siklus II

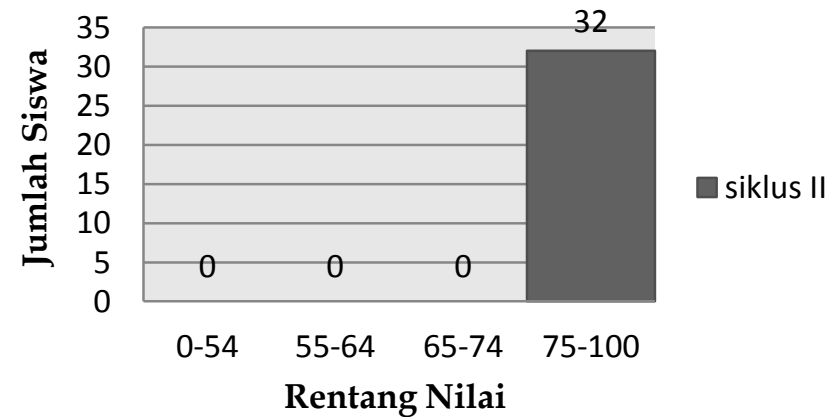

Gambar 3. Diagram Aktivitas Belajar Siswa Siklus II

Dari data hasil observasi terhadap aktifitas belajar siswa terdapat empat aspek yang dinilai kepada 32 siswa, dimana semua siswa memperoleh kategori Sangat Aktif. Sesuai 
dengan data tersebut maka aktifitas siswa sudah berhasil, dimana dimana semua siswa Sangat Aktif.

\subsection{Hasil Belajar Siswa Siklus II}

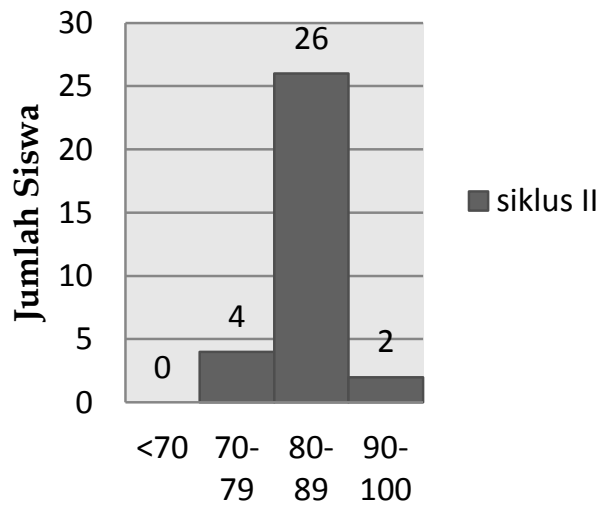

Rentang Nilai

Gambar 4. Diagram Hasil Belajar Siswa Siklus II

Dari hasil belajar siswa yang diperoleh siswa pada waktu pelaksanaan tindakan selesai maka diketahui nilai hasil belajar siswa siklus II dengan kategori tidak kompeten tidak ada, kategori cukup kompeten 26 orang $(81,25 \%)$, kategori kompeten 4 orang (12,5\%) dan kategori sangat kompeten sebanyak 2 orang $(6,25 \%)$.

Berdasarkan hasil pengamatan selama proses belajar mengajar pada siklus II ini, dapat dilihat bahwa aktifitas dan hasil belajar siswa mengalami peningkatan, hampir semua siswa telah terbiasa dengan model pembelajaran NHT. Pada siklus II ini, siswa yang awalnya mayoritas pasif mulai berani untuk memberikan tanggapan, menjawab pertanyaan dan mengajukan pertanyaan. Selain itu, pada siklus ini, pemikiran siswa mulai berkembang dan dapat menghubungkan materi pelajaran dengan kehidupannya. Hal ini dapat terlihat dari tanggapan-tanggapan dan pertanyaan yang diajukan oleh siswa tersebut yang signifikan dari siklus I ke siklus II. Hal ini membuktikan bahwa siklus selanjutnya tidak perlu dilakukan lagi. Oleh karena itu penerapan model pembelajaran NHT dapat meningkatkan aktifitas dan hasil belajar MRAB siswa SMK Negeri 1 Balige.

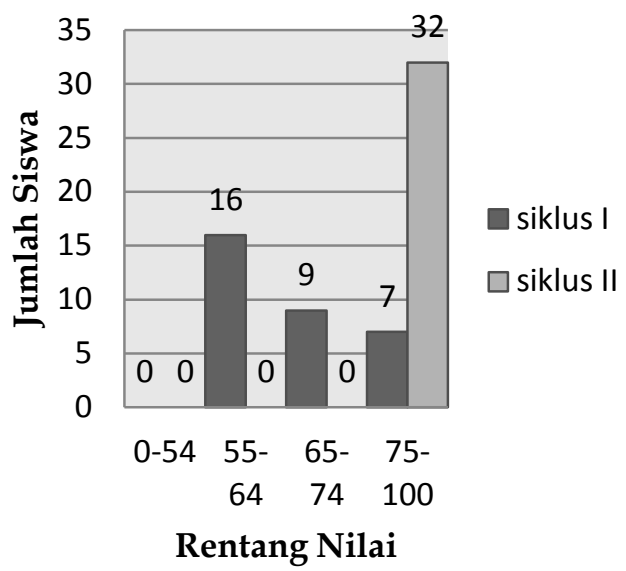

Gambar 6. Diagram Indikator Keberhasilan Aktivitas Belajar Siswa

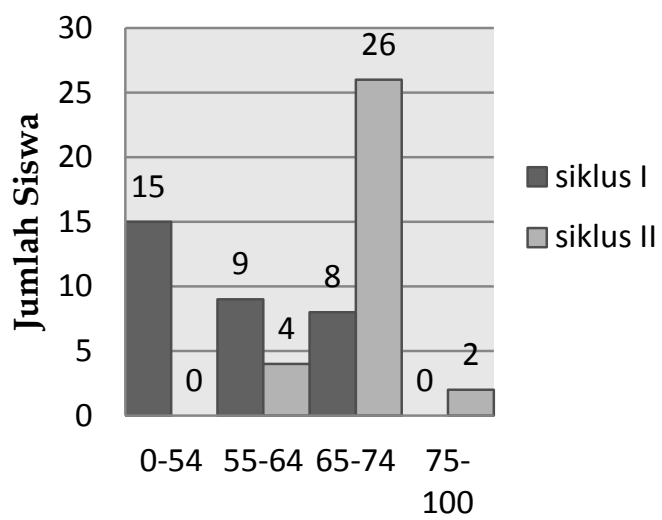

Rentang Nilai

Gambar 7. Diagram Peningkatan Hasil
Belajar Siswa

Dari diagram di atas dapat kita lihat terjadi peningkatan yang signifikan dari siklus I ke siklus II. Hal ini membuktikan bahwa siklus selanjutnya tidak perlu dilakukan lagi. Oleh karena itu penerapan model pembelajaran NHT dapat meningkatkan aktifitas dan hasil belajar MRAB siswa kelas XI Teknik Konstruksi Batu dan Beton SMK Negeri 1 Balige.

\subsection{Pembahasan Hasil Penelitian}

Berdasarkan uraian di atas, dapat dikemukakan bahwa salah satu ciri khas penelitian tindakan kelas adalah adanya siklussiklus yang merupakan suatu proses pemecahan menuju praktek pembelajaran yang lebih baik. Peneliti melakukan pembelajaran dengan menggunakan model pembelajaran 
NHT pada materi menghitung volume stuktur pada siklus pertama dan menghitung volume non struktur pada siklus kedua. Model pembelajaran NHT dapat digunakan untuk meningkatkan aktifitas dan hasil belajar MRAB.

Dari hasil aktifitas dan hasil belajar siswa pada siklus pertama masih ada kekurangan yang perlu diperbaiki antara lain siswa masih canggung dengan model pembelajaran NHT pemikiran siswa masih belum berkembang dan mayoritas siswa masih pasif, dalam arti belum ada yang memberi tanggapan pada materi pelajaran, masih sedikit siswa yang menjawab pertanyaan yang diajukan, dan belum ada pertanyaan yang berasal dari siswa. Dari tahap refleksi dan perencanaan ulang serta untuk perbaikan pada siklus pertama maka peneliti dan guru membuat perencanaan pada siklus kedua yaitu dengan lebih mengembangkan pemikiran siswa dengan cara memberikan lebih banyak ilustrasi keterkaitan anatara materi pelajaran dengan kahidupan sehari-hari. Selain itu, guru juga memberikan lebih banyak pertanyaan dan memberikan nilai tambahan bagi siswa yang mampu menjawab pertanyaan baik yang berasal dari guru, maupun dari siswa itu sendiri, dan juga bagi siswa yang meberikan tanggapan terhadap materi pelajaran. Dengan perencanaan ulang serta perbaikan yang telah dilakukan, pada siklus II aktifitas dan hasil belajar siswa mengalami peningkatan. Hal ini dapat dilihat dari perubahan nilai aktifitas siswa yang Aktif dari 5 orang menjadi 6 orang dan kategori Sangat Aktif dari 8 menjadi 19 orang. Sedangkan untuk hasil belajar siswa dalam kategori Tidak Kompeten dari 12 orang menjadi 0, kategori Cukup Kompeten dari 7 orang menjadi 3 orang, kategori Kompeten dari 6 orang menjadi 21 orang dan kategori Sangat Kompeten dari 0 menjadi 1 orang. Sehingga penerapan model pembelajaran NHT dapat meningkatkan aktifitas dan hasil belajar MRAB siswa kelas XI Teknik Konstruksi Batu dan Beton SMK Negeri 1 Balige.

\section{Kesimpulan, Implikasi dan Saran \\ 5.1 Kesimpulan}

Dari hasil analisis data dan pembahasan maka dapat diambil kesimpulan dari penelitian, yaitu:

a. Penerapan Model Pembelajran Numbered Heads Together (NHT) dapat meningkatkan aktifitas siswa pada mata pelajaran Menyusun Rencana Anggaran Biaya . Hal ini dapat dilihat dari perolehan nilai aktifitas siswa pada siklus I ke siklus II dengan penilaian kategori Kurang Aktif dari 0 orang menjadi 0 , kategori Cukup Aktif dari 12 orang menjadi 0, kategori Aktif dari 7 orang menjadi 0, dan kategori Sangat Aktif dari 6 menjadi 25 orang.

b. Penerapan Model Pembelajran NHT dapat meningkatkan hasil belajar siswa pada mata pelajaran MRAB. Hal ini dapat dilihat dari peningkatan nilai siswa dari siklus I ke siklus II dengan kategori Tidak Kompeten dari 12 orang menjadi 0 , kategori Cukup Kompeten dari 7 orang menjadi 3 orang, kategori Kompeten dari 6 orang menjadi 21 orang dan kategori Sangat Kompeten dari 0 menjadi 1 orang

\subsection{Implikasi}

Berdasarkan hasil penelitian dan kesimpulan penelitian diberikan implikasi sebagai berikut:

a. Dengan diterimanya hipotesis pertama, maka perlu menjadi bahan pertimbangan bagi pihak sekolah maupun guru dalam menerapkan Model Pembelajaran NHT untuk meningkatkan aktifitas siswa pada mata pelajaran MRAB.

b. Dengan diterimanya hipotesis kedua, maka perlu menjadi pertimbangan bagi pihak sekolah maupun guru dalam menerapkan Model Pembelajaran NHT untuk meningkatkan hasil belajar siswa pada mata pelajaran MRAB.

\subsection{Saran}

Berdasarkan kesimpulan di atas, maka disarankan beberapa hal sebagai berikut:

a. Sebaiknya guru mengembangkan pemikiran siswa sebelum memulai suatu materi pelajaran.

b. Guru sebaiknya memberikan nilai tambahan kepada siswa yang mengajukan pertanyaan, menjawab pertanyaan, dan memberikan tanggapan selama proses belajar mengajar, karena dapat memotivasi siswa agar lebih aktif.

c. Bagi para guru, khususnya mata pelajaran MRAB, sebaiknya menerapkan model 
pembelajaran NHT untuk meningkatkan aktifitas dan hasil belajr siswa.

d. Untuk peneliti selanjutnya, dapat menggunakan judul yang sama namun untuk waktu yang lebih lama dengan sumber yang lebih luas, agar dapat dijadikan suatu studi perbandingan bagi guru dalam meningkatkan kualitas pendidikan khususnya pada mata pelajaran MRAB.

\section{Daftar Pustaka}

Abidin, Yunus. 2014. Desain Sistem Pembelajaran Dalam Konteks Kurikulum 2013. Bandung : Refika Aditama.

A.M, Sardiman. 2011. Interaksi dan Motivasi Belajar Mengajar. Jakarta : Rajawali press.

Arikunto, Suharsimi. 2009. Dasar-Dasar Evaluasi Pendidikan. Jakarta : Bumi Aksara. 2008. Metode Penelitian. Jakarta: Bumi Aksara.

2012. Penelitian Tindakan Kelas. Jakarta: Bumi Aksara.

Christina. 2009. Menghitung RAB Pembangunan Rumah. Jakarta: Med Press.

Ginting, Raden. 2015. Penerapan Model Pembelajaran Kontekstual Untuk Meningkatkan Aktivitas dan Hasil Belajar Ukur Tanah Siswa SMK Negeri 1 Lubuk Pakam. Skripsi, Fakultas Teknik, Universitas Negeri Medan, Medan.

Hamalik, O. 2009. Proses Belajar Mengajar. Jakarta : Bumi Aksara.

Istarani. 2012. 58 Model Pembelajaran. Media Persada: Medan.

Jamiah, Y. 2013. Peningkatan Aktivitas Belajar Siswa Kelas VII SMP pada Bilangan Pecahan dengan Teori Bruner (Online). (http://download.portalgaruda.org/ar ticle.php?article $=130015 \& \mathrm{val}=2338 \&$ titl e=PENINGKATAN $\% 20$ AKTIVITAS $\% 2$ 0BELAJAR\%20SISWA \%20KELAS\%20V II\%20SMP\%20PADA \%20BILANGAN\% 20PECAHAN\%20DENGAN\%20TEORI \%20BRUNER, diakses 20 Februari 2015).

Lie, Anita. 2010. Cooperative Learning. Jakarta: Gramedia Widiasarana Indonesia.
Sabri, Ahmad. 2010. Strategi Belajar Mengajar Dan Micro Teaching. Ciputat: Quantum Teaching.

Siahaan, Rizaldi. 2014. Penerapan Model Pembelajaan Kooperatif Tipe Stad (Student Teams Achievement Divisions) Untuk Meningkatkan Aktivitas Dan Hasil Belajar Menyusun Rencana Anggaran Biaya Siswa Kelas XI Program Keahlian Teknik Konstruksi Batu Dan Beton SMK Negeri 1 Balige. Skripsi, Fakultas Teknik, Universitas Negeri Medan, Medan.

Slameto. 2010. Belajar Dan Faktor-Faktor Yang Mempengaruhinya. Jakarta: Rineka Cipta.

Slavin, R E. 2005. Cooperative Learning : Theory, Research And Practice. Bandung: Nusa Media.

Sudjana, N. 2009. Penilaian Hasil Proses Belajar Mengajar. Bandung: Remaja Rosdakarya.

Trianto. 2009. Mendesain Model Pembelajaran Inovatif Progresif Konsep Landasan Dan Implementasinya Pada Kurikulum Tingkat Satuan Pendidikan. Jakarta : Kencana Prenada Media Group. 